\title{
Microsatellite diversity and chromosome number in natural populations of Trifolium riograndense Burkart
}

\author{
Ionara Fatima Conteratoํㅜ ${ }^{1}$ Miguel Dall'Agnol ${ }^{1}$, Maria Teresa Schifino-Wittmann ${ }^{1 *}$, Aline Janke ${ }^{2}$
}

IUFRGS/FA - Depto. de Plantas Forrageiras e Agrometeorologia, C.P. 15100 - 91501-970 - Porto Alegre, RS - Brasil.

2UFRGS/Instituto de Biociências - Depto. de Genética, C.P. 15053 - 91501-970 - Porto Alegre, RS - Brasil.

*Corresponding author <mtschif@ufrgs.br>

Edited by: Antonio Costa de Oliveira

Received March 18, 2011

Accepted August 04, 2011

\begin{abstract}
Twenty eight natural populations of Trifolium riograndense Burkart, an important forage legume from native pastures of the state of Rio Grande do Sul, Brazil, were evaluated for genetic diversity with eight Simple Sequences Repeats (SSR) markers. Chromosome numbers were also determined. The eight markers were polymorphic, with 35 alleles and an average of 4.37 alleles per locus, and Polymorphism Information Content (PIC) between 0.48 and 0.80 . Group analysis based on Jaccard's similarity coefficient separated the 28 accessions in nine groups, with an average genetic similarity of 0.44 , indicating a high genetic variability among the populations. No evident relation between genetic distance and geographical origin was detected. The chromosome number of $2 n=2 x=16$ was found in all populations, indicating lack of intraspecific variability for chromosome number in the species. This information on diversity can be used in conservation strategies as well as in genetic breeding programs of this species. Keywords: native clover, genetic diversity, cytogenetics, native pastures
\end{abstract}

\section{Introduction}

The native pastures of Rio Grande do Sul, the southernmost State of Brazil are the basis for cattle raising, comprising $76 \%$ of used pasture areas (Nabinger et al., 2009). Trifolium L. is a widely distributed group with ca. 255 species, some of them extensively cultivated as forage and green manure (Zohary and Heller, 1984; Repková et al., 2006). Trifolium riograndense Burkart is an important component of Rio Grande do Sul native pastures. It is a prostrate and stoloniferous species. For plant breeders, the species is attractive due to its qualities as perenity, cold tolerance and tolerance to soils with high aluminum and manganese contents (Kappel, 1967; Moraes et al., 1989). Previous studies with few accessions of the species disclosed a high intraspecific variation when isoenzymatic (Lange and Schifino-Wittmann, 2000), SSR markers (Dalla Rizza et al., 2007) and morphoagronomic characteristics (Conterato et al., 2010a) were used.

Microsatellites (SSR, Simple Sequences Repeats) are codominant, multiallelic, highly reproducible and polymorphic molecular markers widely used in plants in genetic research, cultivar characterization, plant breeding, paternity tests and phylogenetic studies among others (Powell et al., 1996; Dalla Rizza et al., 2007; Real et al., 2007; Dias et al., 2008; Santos et al., 2010; Zhang et al., 2010).

In order to know and to preserve genetic resources, genetic diversity must be evaluated (Lane et al., 2000) and collections and germplasm banks should be undertaken (Valls et al., 2009). Despite previous studies with the species, no comprehensive study to assess its genetic variability with molecular markers has been carried on. Therefore, this study aimed to evaluate genetic diversity using SSR markers, as well as verify the existence, or not, of intraspecific variability in chromosome numbers, in natural populations of
T. riograndense (most of them also studied morphologically and agronomically by Conterato et al. (2010a).

\section{Materials and Methods}

Seeds from 28 accessions (naturally occurring populations) of $T$. riograndense were collected along the species area of distribution in physiographic regions of Rio Grande do Sul (Table 1). In each locality, at least 30 inflorescences with mature legumes were collected from at least 30 plants around a ca. $50 \mathrm{~m}^{2}$ area. Afterwards, the legumes of each accessions were opened and the seeds bulked.

Seeds of each accession were scarified with sandpaper and germinated in Petri dishes and the young plants transferred individually to $34 \times 11.5 \mathrm{~cm}$ containers with garden soil and kept in an open experimental area. Total genomic DNA of each sample (100-150 ng) was extracted from a bulk of young leaves of ten plants per accession (except accession 34, from which only three plants persisted) following Doyle and Doyle (1987) protocol, with slight modifications. DNA concentration and quality were evaluated in $1 \%$ agarose gel, using 100 and $500 \mathrm{ng}$ fago $\lambda$ DNA as standard.

Five microsatellite primers developed for Trifolium repens L. and 14 primers developed for Lotus japonicus L. (Regel) Larsen were tested and from these eight were selected according the quality of amplified fragments (Table 2). PCR reactions were prepared in a final volume of $7 \mu \mathrm{L}$ per reaction, containing $1 \mu \mathrm{L}$ of the work DNA solution $\left(20 \mathrm{ng} \mu \mathrm{L}^{-1}\right), 1 \mu \mathrm{L}$ of PCR $10 \mathrm{X}$ buffer, $0.6 \mu \mathrm{L}$ of $\mathrm{MgCl}_{2}(50 \mathrm{nM}), 0.8 \mu \mathrm{L}$ of DNTP mix containing 2.5 $\mathrm{mM}$ of each of the four nucleotides, $0.6 \mu \mathrm{L}$ of the forward primer $(10 \mu \mathrm{M}), 0.6 \mu \mathrm{L}$ of the reverse primer $(10$ $\mu \mathrm{M}), 0.2 \mu \mathrm{L}$ of Taq polimerase Quiagen $\left(5 \mathrm{U}_{\mu} \mathrm{L}^{-1}\right)$ and sterilized water to complete the volume. PCR conditions followed Dias et al. (2008) with the following modifica- 
Table 1 - Accessions of $T$. riograndense analyzed, including place of collection (municipality), respective physiographic region and chromosome number.

\begin{tabular}{|c|c|c|c|}
\hline Accession & Place of collection* & $\begin{array}{l}\text { Physiographic } \\
\text { region** }\end{array}$ & $2 n$ \\
\hline 01 & S. F. Paula $\left(29^{\circ} 26^{\prime} \mathrm{S}, 50^{\circ} 35^{\prime} \mathrm{W}\right)$ & C. Cima da Serra & \\
\hline 03 & 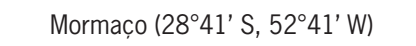 & Planalto Médio & \\
\hline 10 & Lagoa Vermelha $\left(28^{\circ} 12^{\prime} \mathrm{S}, 51^{\circ} 31^{\prime} \mathrm{W}\right)$ & C. Cima da Serra & \\
\hline 11 & S.F.Paula $\left(29^{\circ} 26^{\prime}\right.$ S, $50^{\circ} 35^{\prime}$ W) & C. Cima da Serra & \\
\hline 15 & Passo Fundo (28 $\left.15^{\prime} \mathrm{S}, 52^{\circ} 24^{\prime} \mathrm{W}\right)$ & Planalto Médio & \\
\hline 17 & Seberi $\left(27^{\circ} 28^{\prime} \mathrm{S}, 53^{\circ} 24^{\prime} \mathrm{W}\right)$ & Alto Uruguai & \\
\hline 18 & $\begin{array}{l}\text { Frederico Westphalen } \\
\left(27^{\circ} 21^{\prime} \mathrm{S}, 53^{\circ} 23^{\prime} \mathrm{W}\right)\end{array}$ & Alto Uruguai & \\
\hline 19 & Tenente Portela $\left(27^{\circ} 22^{\prime} \mathrm{S}, 53^{\circ} 45^{\prime} \mathrm{W}\right)$ & Alto Uruguai & \\
\hline 20 & Bom Jesus $\left(28^{\circ} 40^{\prime} \mathrm{S}, 50^{\circ} 25^{\prime} \mathrm{W}\right)$ & C. Cima da Serra & $2 n=$ \\
\hline 21 & Passo Fundo (28 $\left.15^{\prime} \mathrm{S}, 52^{\circ} 24^{\prime} \mathrm{W}\right)$ & Alto Uruguai & \\
\hline 23 & B. V. Missões $\left(27^{\circ} 39^{\prime}\right.$ S, $53^{\circ} 18^{\prime}$ W) & Planalto Médio & \\
\hline 29 & Muitos Capões (28¹8'S, $51^{\circ} 10^{\prime}$ W) & C. Cima da Serra & $2 n=$ \\
\hline 30 & Tio Hugo (28³4' S, $52^{\circ} 35^{\prime}$ W) & Planalto Médio & $2 n=$ \\
\hline 33 & $\begin{array}{l}\text { Palmeira das Missões (275ㄱ' S, } \\
\left.53^{\circ} 18^{\prime} \mathrm{W}\right)\end{array}$ & Planalto Médio & \\
\hline 34 & Taquara $\left(52^{\circ} 96^{\prime} \mathrm{S}, 73^{\circ} 85^{\prime} \mathrm{W}\right)$ & $\begin{array}{l}\text { Enc. Inf. } \\
\text { Nordeste }\end{array}$ & \\
\hline 41 & Lagoa Vermelha $\left(28^{\circ} 12^{\prime} \mathrm{S}, 51^{\circ} 31^{\prime} \mathrm{W}\right)$ & C. Cima da Serra & \\
\hline 42 & $\begin{array}{l}\text { Frederico Westphalen }\left(27^{\circ} 21^{\prime} \mathrm{S},\right. \\
\left.53^{\circ} 23^{\prime} \mathrm{W}\right)\end{array}$ & Alto Uruguai & \\
\hline 43 & $\begin{array}{c}\text { Palmeira das Missões }\left(27^{\circ} 53^{\prime} \mathrm{S},\right. \\
\left.53^{\circ} 18^{\prime} \mathrm{W}\right)\end{array}$ & Planalto Médio & \\
\hline 45 & 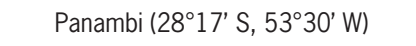 & Planalto Médio & $2 n=$ \\
\hline 46 & Cruz Alta $\left(28^{\circ} 38^{\prime} \mathrm{S}, 53^{\circ} 36^{\prime} \mathrm{W}\right)$ & Planalto Médio & $n=$ \\
\hline 49 & Itaara $\left(29^{\circ} 36^{\prime} \mathrm{S}, 53^{\circ} 45^{\prime} \mathrm{W}\right)$ & D. Central & $2 n=$ \\
\hline
\end{tabular}

*S. F. Paula: São Francisco de Paula municipality; *B. V. Missões: Boa Vista das Missões municipality; *Tainhas and Lajeado Grande are districts from São Francisco de Paula; **C. Cima da Serra: Campos de Cima da Serra; **D. Central: Depressão Central; **Enc. Inf. Nordeste: Encosta Inferior do Nordeste.

tions: initial denaturation at $94{ }^{\circ} \mathrm{C}$ for $5 \mathrm{~min}$, followed by seven cycles of $1 \mathrm{~min}$ at $94{ }^{\circ} \mathrm{C}, 1 \mathrm{~min}$ at $61{ }^{\circ} \mathrm{C}, 1$ min at $72{ }^{\circ} \mathrm{C}$, and annealing temperature reduction of $1{ }^{\circ} \mathrm{C}$ per cycle, followed by 25 cycles of $1 \mathrm{~min}$ at 94 ${ }^{\circ} \mathrm{C}, 1 \mathrm{~min}$ at $55^{\circ} \mathrm{C}$ and $1 \mathrm{~min}$ at $72{ }^{\circ} \mathrm{C}$ and six cycles of 45 seconds at $94{ }^{\circ} \mathrm{C}, 45$ seconds at $54{ }^{\circ} \mathrm{C}$ and $45 \mathrm{sec}$ onds at $72{ }^{\circ} \mathrm{C}$ and a final extension for $8 \mathrm{~min}$ at $72{ }^{\circ} \mathrm{C}$ and storage at $7{ }^{\circ} \mathrm{C}$. The amplification products were separated in a $4 \%$ high resolution agarose gel (Agarose 1000) stained with $0.08 \mu \mathrm{L} \mathrm{mL}^{-1}$ ethidium bromide (10 $\mathrm{mg} \mathrm{mL}^{-1}$ ) and immersed in TBE $1 \mathrm{X}$ buffer under an electrophoretic current of $96 \mathrm{~V}$ for approximately $1 \mathrm{~h}$ and $15 \mathrm{~min}$. After electrophoresis, the gel was visualized in an ultraviolet light (wavelength of $260 \mathrm{~nm}$ ) and photographed in order to compare the samples frag- ments with a 100 base pair (bp) ladder, by using the Kodak EDAS 290 (Electrophoresis Documentation and Analysis System) program.

The dendrogram of genetic similarity among accessions was obtained from the similarity coefficients using the UPGMA (Unweighted Pair-Group Method Using an Arithmetic Average). Cluster analysis was performed using the Numerical Taxonomy and Multivariate Analysis System" NTSYSpc program version 2.1 (Rohlf, 2001) and the similarity matrix constructed with Jaccard's coefficient. The total number of alleles per locus (A), the allelic frequencies and the Polymorphism Information Content (PIC) for each locus (PICi $=1-\sum \mathrm{P}_{\mathrm{i}}$, where $\mathrm{P}_{\mathrm{i}}$ is the frequency of allele I band) were calculated.

Seeds were scarified with sandpaper and germinated in Petri dishes with moist filter paper. Emerging roots with $1-\mathrm{cm}$ length were collected, pretreated with a saturated solution of paradichlorobenzene for 12 to $22 \mathrm{~h}$ at $4{ }^{\circ} \mathrm{C}$, fixed in 3:1 ethanol-acetic acid, stained by the Feulgen procedure for 3 to $4 \mathrm{~h}$, treated with 2 $\%$ pectinase for 1 to 2 minutes and macerated in propionic carmine, following Dahmer et al. (2009). At least ten intact cells with good chromosome spreading were analyzed per seedling, an average of four seedlings per accession. The results were recorded by photomicrographs and with the aid with a digital image capturing system.

\section{Results and Discussion}

The eight SSR primers showed transferability between Trifolium repens and Lotus corniculatus and T. riograndense, generating 35 alleles ranging in size from 102 to 407 base pairs. Average number of alleles per locus was 4.37, ranging from three (SSR ats070) to six (SSR TRSSRAXX31) (Table 2). A similar result, with an average of 4.8 alleles per locus was reported by Kölliker et al. (2001) in T. repens. In T. pratense, Dias et al. (2008), also using SSR found high intrapopulational variability in a core collection of red clover (T. pratense), number of alleles per locus ranging from seven to 12 . Null alleles, those alleles that are consistently not amplified (Martins et al., 2008) were observed in SSR ats 070, TM0133 and TM0256 (Table 2). Null alleles have been found in more than $25 \%$ of the microsatellite loci, reaching frequencies over $15 \%$ (Jarne and Lagoda, 1996) and observed in other plants such as Allium cepa L. cultivars (Santos et al., 2010) and Copaifera langsdorffii Desf. (Martins et al., 2008), among others. Null alleles may be due mainly to the lack of a sequence for the initiatior annealing, due to point mutations. This fact can: (i) difficult parentage analysis interpretations (Dakin and Avise, 2004); (ii) provide an erroneous detection the amount of homozygote genotypes per locus (White et al., 1999); and (iii) cause deviations in Hardy-Weinberg balance leading to wrong conclusions on populations genetic diversity (Martins et al., 2008). 
PIC values, which reflects diversity and allelic frequency, varied among $T$. riograndense populations from 0.48 to 0.80 , with an average of 0.68 (Table 2), outlining high intrapopulation variability. In T. polymorphum, Real et al. (2007) detected PIC values from 0.52 to 0.86 . In the two accessions of $T$. riograndense analysed with ISSR (Inter Simple Sequence Repeats) by Dalla Rizza et al. (2007), intraspecific variability was 0.78 .

The average similarity among accessions was 0.44 (Figure 1), ranging from 0.28 to 0.77 , outlining the high genetic variability among the $28 \mathrm{~T}$. riograndense accessions analyzed, what is expected in an allogamous spe- cies. The cophenetic correlation coefficient of the dendrogram (Figure 1), was 0.69 , below the 0.80 considered by Sokal and Rohlf (1962) as indicative of a good adjustment between the original distance matrix and the graphic distance, therefore there may be some incongruities in the grouping of the 28 accessions, that could also been affected by sample size. Incongruities in clustering have also been reported by other authors such as Santos et al. (2010) in Allium cepa, Vieira et al. (2005) in Zea mays and Rocha et al. (2010) in potato cultivars. Using the average similarity of 0.44 as cutting point, nine groups were formed: group 1 (accessions 1, 9, 10), group 2 (accessions

Table 2 - Characteristics of the eight primers of microsatellite markers used in the 28 accessions of T. riograndense.

\begin{tabular}{|c|c|c|c|c|c|}
\hline Primer & Motif & Primer sequence & Allele size (pb) & Allele number & PIC \\
\hline *TRSSRAXX31 & $(\mathrm{GT})_{7}$ & $\begin{array}{l}\text { F: TCTGTTTTGTTGGCCATGC } \\
\text { R: TTGCAAAGTGTTTGGAAGGA }\end{array}$ & $407-207$ & 06 & 0.80 \\
\hline *Ats070 & $(C A)_{n}$ & $\begin{array}{l}\text { F: CATCTACTCACCACCACCTA } \\
\text { F: CAGCAGCAGCAGCAGCGATA }\end{array}$ & $401-278$ & 03 & 0.62 \\
\hline *Ats226 & $(A T G)_{n}$ & $\begin{array}{l}\text { F: CATCTACTCACCACCACCTA } \\
\text { F: CAGCAGCAGCAGCAGCGATA }\end{array}$ & $381-155$ & 05 & 0.75 \\
\hline "Prs582 & $(\mathrm{GAA})_{\mathrm{n}}$ & $\begin{array}{l}\text { F: CCGGTTCGATTCAACAAGTT } \\
\text { R:CTGCAGATCCAGTAATGATTTCC }\end{array}$ & $360-227$ & 05 & 0.78 \\
\hline **TM0133 & $(\mathrm{CT})_{24}$ & $\begin{array}{l}\text { F: CTTTGAAATAACTCATCAAAC } \\
\text { R: TACTGACACATTCCCCTTGC }\end{array}$ & $350-102$ & 04 & 0.76 \\
\hline$*$ TM0021 & $(\mathrm{CT})_{16}$ & $\begin{array}{l}\text { F: ACGAAAACAAAACCCTGCTG } \\
\text { R: CTGTTGTATCAAGCCACAAG }\end{array}$ & 290-147 & 04 & 0.62 \\
\hline *TM0256 & $(\mathrm{AAAT})_{7}$ & $\begin{array}{l}\text { F: GAAATTCTTTCCATTCATTG } \\
\text { R: AGAGAGATAGGGTTGCTCAC }\end{array}$ & $375-142$ & 04 & 0.68 \\
\hline **TM0212 & $(\mathrm{CT})_{13}$ & $\begin{array}{l}\text { F: CTTCCTTCCTCACCACTTAG } \\
\text { R: TAAACGAAAATGAAGCAGAG }\end{array}$ & 295-102 & 04 & 0.48 \\
\hline Total & & & & 35 & \\
\hline Averages & & & & 4.37 & 0.68 \\
\hline
\end{tabular}

"Primer developed for Trifolium repens L.; "*Primer developed for Lotus japonicus (Regel) Larsen; Allele number: total number of alleles per locus; PIC: Polymorphism Information Content for each locus.

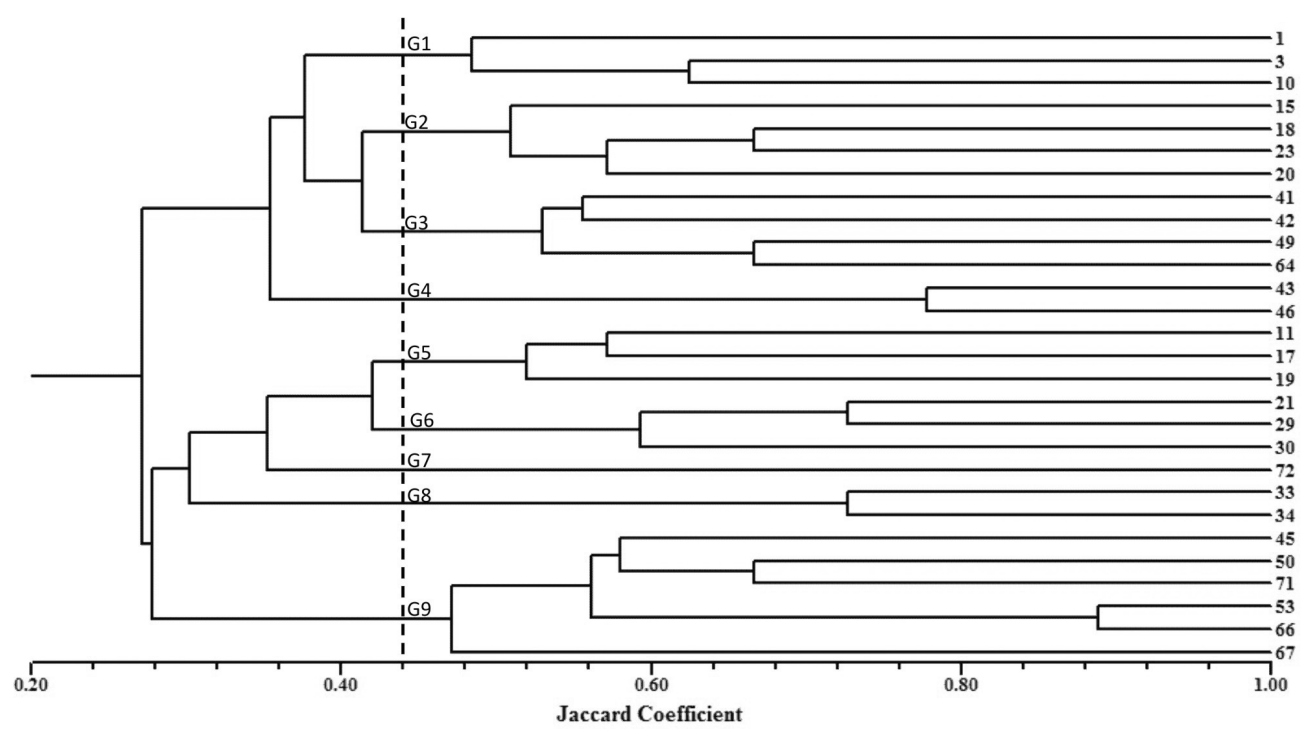

Figure 1 - Dendrogram of genetic similarity based on Jaccard Coefficient for 28 accessions of T. riograndense using SSR markers. The dashed line points to the average similarity and cutting point. G1, G2, G3, G4, G5, G6, G7, G8 and G9 indicate the nine groups. 
$15,18,23,20)$, group 3 (accessions 4, 42, 49, 64), group 4 (accessions 43, 46), group 5 (accessions 11, 17, 19), group 6 (accessions 21, 29, 30), group 7 (accession 72), group 8 (accessions 33, 34) and group 9 (accessions 45, 50, 71, 53, $66,67)$. Accessions located in different groups such as 1 , $64,11,72,50,71,53,66$ and 67 were all collected in São Francisco de Paula (Table 1) indicating the high diversity of $T$. riograndense in the Campos de Cima da Serra physiographic region, where the species is more abundant. On the other hand, the two most similar accessions (53 and 66) where also collected in this region. Both accessions 18 and 42, and 43 and 33, collected near urban areas in Frederico Westphalen and Palmeira das Missões, respectively, were located in different groups in the dendrogram (Figure 1) suggesting that genetic diversity may be high in the species even in populations growing near disturbed habitats.

No clearcut relation between genetic diversity assessed by SSR and geographical origin could be established in the present study, same as reported by Dias et al. (2008) for T. pratense. In Trifolium repens, Zhang et al. (2010) observed some relationship between genetic diversity and geographical origin and in Lotus corniculatus genetic distances and place of collection were highly correlated (Sardaro et al., 2008).

Conterato et al. (2010a) evaluated morphological and agronomically most of the accessions also studied in this study and found high diversity for these characteristics, not correlated with geographical origin. The groups formed by the use of these morphoagronomic descriptors, by the Tocher methods, were nor the same as those of the present work, indicating no clear relation between morphological and molecular variability, same as found in, for example, Trifolium pratense (Greene et al., 2004) and Lotus corniculatus (Steiner and Los Santos, 2001). Morphoagronomic descriptors are associated to gene expression and suffer environmental influence, modulating the phenotype. On the other hand, molecular markers, including microsatellites, are mostly neutral (Gouvêa et al., 2010).

All populations analyzed had $2 \mathrm{n}=2 \mathrm{x}=16$ chromosomes (Table 1, Figure 2) confirming previous reports for the species (Schifino-Wittmann and Moraes-Fernandes, 1988) and indicating absence of intraspecific variability for chromosome number in the species. In the genus Trifolium the most common basic chromosome number is $\mathrm{x}=8$, found in $80 \%$ of the species, and most of them are diploid (Zohary and Heller, 1984), same as T. riograndense and the other two Trifolium species native in Rio Grande do Sul, T. polymorphum (Schifino-Wittmann and Moraes-Fernandes, 1988) and T. argentinense (Conterato et al., 2010b).

\section{Acknowledgements}

To Conselho Nacional de Desenvolvimento Científico e Tecnológico (CNPq, Brazil, Edital Universal 2007, proc. 471015/2007-5), and Fundação de Amparo à Pes-

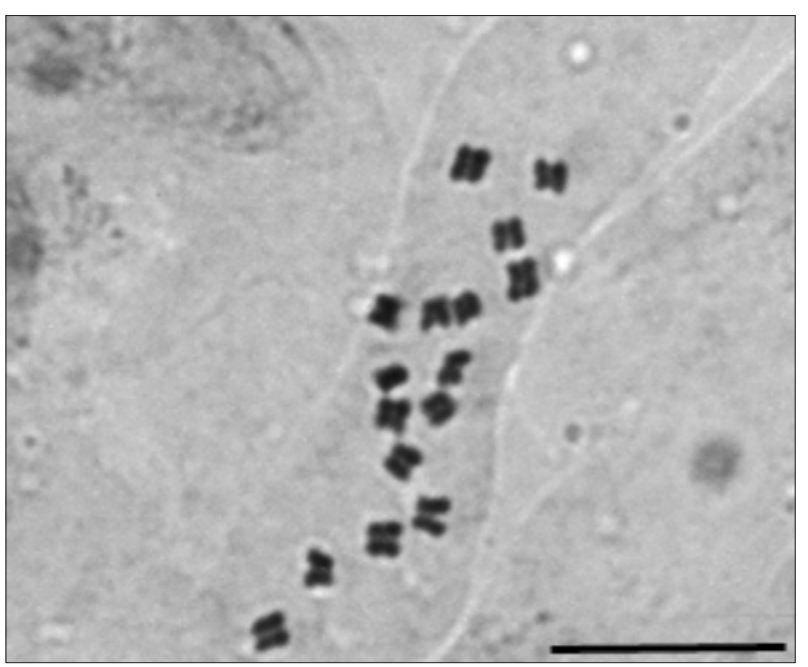

Figure 2 - Somatic metaphase chromosome of $T$. riograndense with $2 n=2 x=16$, accession 46 - Cruz Alta. Scale bar equal to $10 \mu \mathrm{m}$.

quisa do Estado do Rio Grande do Sul (FAPERGS, Brazil) for financial support and grants.

\section{References}

Conterato, I.F.; Dall' Agnol, M.; Schifino-Wittmann, M.T.; Pontalti, G.C.; Almeida, D. 2010a. Morphoagronomic variation in natural populations of Trifolium riograndense Burkart. Scientia Agricola 67: 675-684.

Conterato, I.F.; Schifino-Wittmann, M.T.; Dall' Agnol, M. $2010 \mathrm{~b}$. Seed dimorphism, chromosome number and karyotype of the amphicarpic species Trifolium argentinense Speg. Genetic Resources and Crop Evolution 57: 727-731.

Dahmer, N.; Schifino-Wittmann, M.T.; Dias, L.A.S. 2009. Chromosome numbers in five populations of physic nut (Jatropha curcas L.). Crop Breeding and Applied Biotechnology 9: 386-389.

Dakin, E.E.; Avise, J.C. 2004. Microsatellite null alleles in parentage analysis. Heredity 93: 504-509.

Dias, P.M.B.; Julier, B.; Sampoux, J.P.; Barre, P.; Dall'Agnol, M. 2008. Genetic diversity in red clover (Trifolium pratense L.) revealed by morphological and microsatellite (SSR) markers. Euphytica 160: 189-205.

Dalla Rizza, M.; Real, D.; Reyno, R.; Porro, V.; Burgueno, J.; Errico, E.; Quesenberry, K.H. 2007. Genetic diversity and DNA content of three South American and three Eurasiatic Trifolium species. Genetics and Molecular Biology 30: 11181124.

Doyle, J.J.; Doyle, J.L. 1987. Isolation of plant DNA from fresh tissue. Focus 12: 13-15.

Gouvêa, L.R.L.; Rubiano, L.B.; Chioratto, A.F.; Zuchi, M.I.; Gonçalves, P.S. 2010. Genetic divergence of rubber tree estimated by multivariate techniques and microsatellite markers. Genetics and Molecular Biology 33: 308-318.

Greene, S.L.; Gritsenko, M.; Vandemark, G. 2004. Relating morphologic and RAPD marker variation to collection site environment in wild populations of red clover (Trifolium pretense L.). Genetic Resources and Crop Evolution 51: 643-653. 
Jarne, P.; Lagoda, P.J.L. 1996. Microsatellites, from molecules to populations and back. Trends in Ecology and Evolution 11: 424429.

Kappel, A. 1967. Clovers: Species of Genus Trifolium. Secretaria da Agricultura do Rio Grande do Sul, Porto Alegre, RS, Brazil (in Portuguese).

Kölliker, R.; Jones, E.S.; Drayton, M.C.; Dupal, M.P.; Forster, J.W. 2001. Development and characterization of simple sequence repeat (SSR) markers for white clover (Trifolium repens L.). Theoretical and Applied Genetics 102: 416-424.

Lane, L.A.; Ayres, J.F.; Lovett, J.V.; Murison, R.D. 2000. Morphological characteristics and agronomic merit of white clover (Trifolium repens L) populations collected from northern New South Wales. Australian Journal of Agricultural Research 51: 985-997.

Lange, O.; Schifino-Wittmann, M.T. 2000. Isozyme variation in wild and cultivated species of the genus Trifolium L. (Leguminosae). Annals of Botany 86: 339-345.

Martins, K.; Santos, J.D.; Gaiotto, F.A.; Moreno, M.A.; Kageyama, P.Y. 2008. Population genetic structure of Copaifera langsdorffii Desf. (Leguminosae - Caesalpinioideae) in forest fragments in "Pontal do Paranapanema", SP, Brazil. Revista Brasileira de Botânica 31: 61-69 (in Portuguese, with abstract in English).

Moraes, C.O.C.; Paim, N.R.; Nabinger, C. 1989. Evaluation of the legumes from genus Trifolium. Pesquisa Agropecuária Brasileira 24: 813-818 (in Portuguese, with abstract in English).

Nabinger, C.; Ferreira, E.T.; Freitas, A.K.; Carvalho, P.C.F.; Sant'Anna, D.M. 2009. Animal production based in native pasture: aplications of research results. p. 175-198. In: Pillar, V.P.; Müller, S.C.; Castilhos, Z.M.S.; Jacques, A.V.A., eds. The South Brazilian Campos: conservation and sustainable use of biodiversity. Ministério do Meio Ambiente, Brasília, DF, Brazil (in Portuguese).

Powell, W.; Machray, G.C.; Provan, J. 1996. Polymorphism revealed by simple sequence repeats. Trends in Plant Science 1: 215-222.

Repková, J.; Jungmannová, B.; Jakesová, H. 2006. Identification of barriers to interspecific crosses in the genus Trifolium. Euphytica 151: 39-48.

Real, D.; Dalla Rizza, M.; Reyno, R.; Quesenberry, K.H. 2007. Breeding system of the aerial flowers in an amphicarpic clover species: Trifolium polymorphum. Crop Science 47: 1401-1406.

Rocha, E.A.; Paiva, L.V.; Carvalho, H.H.; Guimarães, C.T. 2010. Molecular characterization and genetic diversity of potato cultivars using SSR and RAPD markers. Crop Breeding and Applied Biotechnology 10: 204-210.
Rohlf, F.J. 2001. NTSYS-pc: Numerical Taxonomy and Multivariate Analysis System: Version 2.1. Exeter Software, New York, NY, USA.

Sardaro, M.L.S.; Atallah, M.; Tavakol, E.; Russi, L.; Porceddu, E. 2008. Diversity for AFLP and SSR in natural populations of Lotus corniculatus L. from Italy. Crop Science 48: 1080-1089.

Santos, C.A.F.; Oliveira, V.R.; Rodrigues, M.A.; Ribeiro, H.L.C. 2010. Molecular characterization of onion cultivars using microsatellite markers. Pesquisa Agropecuária Brasileira 45: 49-55 (in Portuguese, with abstract in English).

Schifino-Wittmann, M.T.; Moraes-Fernandes, M.I.B. 1988. Chromosome numbers, karyotypes and meiotic behavior of populations of some Trifolium (Leguminosae) species. Brazilian Journal of Genetics 11: 379-390.

Sokal, R.R.; Rohlf, F.J. 1962. The comparison of dendrograms by objective methods. Taxon 11: 30-40.

Steiner, J.J.; Los Santos, G.G. 2001. Adaptative ecology of Lotus corniculatus L. genotypes. I. Plant morphology and RAPD marker characterization. Crop Science 41: 552-563.

Valls, J.F.M.; Boldrini, I.I.; Longhi-Wagner, H.M.; Miotto, S.T.S. 2009. The floristic patrimony of Campos: potentiality of use and conservation of their genetic resources. p. 139-154. In: Pillar, V.P.; Müller, S.C.; Castilhos, Z.M.S.; Jacques, A.V.A., eds. The South Brazilian Campos: conservation and sustainable use of biodiversity. Ministério do Meio Ambiente, Brasília, DF, Brazil (in Portuguese).

Vieira, E.A.; Zimmer, P.D.; Oliveira, A.C.; Carvalho, F.I.F.; Malone, G.; Benini, G. 2005. Use of graphic models in maize parental selection for hybridization and mapping. Ciência Rural 35: 986-994 (in Portuguese, with abstract in English).

White, G.M.; Boshier, D.H.; Powell, W. 1999. Genetic variation within a fragmented population of Swietenia humilis Zucc. Molecular Ecology 8: 1899-1909.

Zhang, X.; Zhang, Y.; Yan, R.; Han, J.; Hong, F.; Wang, J.H.; Cao, K. 2010. Genetic variation of white clover (Trifolium repens L.) collections from China detected by morphological traits, RAPD and SSR. African Journal of Biotechnology 9: 3032-304.

Zohary, M.; Heller, D. 1984. The Genus Trifolium L. The Israel Academy of Sciences and Humanities, Jerusalem, Israel. 